Strategi Mengatasi Kemiskinan...... | Wahyu Iryana

\title{
STRATEGI MENGATASI KEMISKINAN NELAYAN ERETAN WETAN, INDRAMAYU
}

\author{
Wahyu Iryana \\ Fakultas Adab dan Humaniora Universitas Islam Negeri \\ Sunan Gunung Djati Bandung \\ Email: wahyu iryana@yahoo.com
}

\begin{abstract}
Indonesia as a maritime country is rich in marine resources. However, most of the people living in coastal or coastal areas, such as the Eretan Wetan community, Indramayu with basic livelihoods of fishermen, especially traditional fishermen and fishermen, are still poor. This can be seen physically from the circumstances of residence or settlement, which looks dense and seemingly slums. The condition of this poor fisherman society is due to several things, including natural poverty, artificial, internal and external. Poverty cannot only be seen from an economic point of view, but it is related to various aspects, one of which is socio-cultural. To overcome the problem of poverty of fishermen, especially in the area of Ereten Wetan, Indramayu, it needs to be integrated in handling the problems. The responsibility of poverty alleviation fishermen not only relies on the government, but all parties involved, including Eretan Wetan own community. Eretan Wetan's poverty alleviation programs need a special strategy that is able to answer the actual conditions, so as to improve the expected well being.
\end{abstract}

Keywords: Strategy, Poverty, Fisherman, Indramayu.

\section{Pendahuluan}

Indonesia dikenal sebagai negara maritim yang memiliki pantai terpanjang di dunia, dengan garis pantai lebih $81.000 \mathrm{~km}$. Dari 67.439 desa di Indonesia, kurang lebih 9.261 desa dikategorikan sebagai desa pesisir. Indonesia juga merupakan negara kepulauan terbesar di dunia dengan 17.508 1997 pulau (Badan Statistik Nasional, 2000). Hal ini menunjukkan bahwa sebagian masyarakat Indonesia tinggal di daerah pantai yang kehidupannya tergantung sumber daya laut dengan mata pencaharian pokok sebagai nelayan. Sebagai bangsa yang memiliki wilayah laut luas dan daratan yangsubur, sudah semestinya Indonesia menjadi bangsa yang makmur. Hal ini menjadi tidak wajar apabila kekayaan yang sedemikian besar ternyata tidak mensejahtrakan penduduknya. Krisis moneter dan ekonomi pada tahun 1997 diyakini sebagai puncak gunung es atas salah kelola negeri ini. Kehancuran sebuah negeri yang kaya namun rakyatnya miskin, tanahnya subur namun sandang pangan sangat mahal. Satu di antaranya yang salah kelola adalah sumber daya kelautan dan perikanan. Sudah puluhan tahun perhatian pada sektor kelautan dan perikanan bisa dikatakan minus. Akibat lebih lanjut, laut dan ikan yang menjadi kekayaan negeri ini terbengkelai dan ironisnya hanya dinikmati beberapa gelintir orang dan bahkan bangsa jiwa lain yang lebih banyak meraup kenikmatan Kondisi tersebut berpengaruh terhadap kehidupan masyarakat 
pesisir atau pantai yang tergantung dari sumber daya kelautan dan perikanan. Pada umumnya kondisi kehidupan masyarakat nelayan tertinggal secara ekonomi, sosial, dan budaya, terutama nelayan tradisional dan nelayan buruh, yang termasuk golongan penduduk miskin. Tujuan tulisan ini berupaya menjadi alternatif solusi sebagai sinergis visi dan misi pemerintahan Joko Widodo-Jusuf Kalla untuk menjadikan penjuru maritim Indonesia sebagai "poros maritim" dunia untuk kemakmuran masyarakat Indonesia, selain itu aspek kekhususan sesungguhnya untuk mengetahui kondisi kehidupan sosial ekonomi dan budaya masyarakat nelayan dan solusi mengatasi masalah kemiskinan masyarakat nelayan di daerah Eretan Wetan, Indramayu.

Kabupaten Indramayu merupakan kabupaten di bagian timur laut Provinsi Jawa Barat atau di sekitar Pantai Utara. Letak ibu kota Kabupaten Indramayu sangat dekat dengan muara Sungai Cimanuk (Ensiklopedi Nasional Indonesia, 1989: 138-140). Wilayah darat Indramayu cukup luas mencapai sekitar 209.942 Ha atau 2.099,42 km² (BPS, 2014: 3-39). Indramayu juga sering disebut sebagai salah satu wilayah di Pesisir Utara Jawa atau Pantai Utara Jawa (Pantura) ${ }^{1}$. Sumber daya alam yang dimiliki berasal dari laut, sawah, dan hutan. Terbentuknya Kabupaten Indramayu sering dikaitkan dengan tokoh Arya Wiralodra yang berasal dari Bagelen, Jawa Tengah (Kasim, 2011: 1). Nama Indramayu sendiri menurut kepercayaan masyarakat berasal dari tokoh bernama Endang Dharma Ayu, tapi ketika orang Belanda datang ke Indramayu terjadi verbastering dari in dermayu menjadi Indramayu (Kasim, 2013: 16). Beberapa penduduk di Desa Eretan terutama yang berdiam di sekitar pesisir pantai memiliki mata pencaharian sebagai nelayan. Para nelayan yang ada di Eretan merupakan nelayan kecil yang menggunakan peralatan relatif sederhana dengan radius pencarian ikannya hanya sekitar pantai atau masih dalam zona Ekonomi Eksklusif (ZEE). Perahu yang digunakan di sekitar pantai merupakan perahu kecil yang di sebut Jukung dengan tenaga penggerak berupa dayung digunakan pula beberapa peralatan untuk menangkap ikan di antaranya kain dan jaring ikan. Kapal lain yang lebih besar adalah jegongan dan sopean, yang hampir di miliki oleh para juragan. Semua perahu terbuat dari kayu yang dilengkapi dengan motor temple yang berkekuatan rata-rata $10 \mathrm{PK}$. Perahu jenis jegongan memiliki lebar antara 1,75-2 meter dengan panjang 6-10 meter berawak antara 2-4 orang, biasanya membawa jaring rampus, yaitu jaring yang lebar untuk menangkap berbagai jenis ikan seperti pari, kakap, tongkol. Sedangkan perahu sopean memiliki lebar anatara 2-2,5 meter dengan panjang kurang lebih12 meter, berawak 3-4 orang. Jaring yang dibawa oleh perahu sopean yaitu jaring kantong yaitu jarring yang dipergunakan untuk menjaring udang. ${ }^{1}$

\footnotetext{
${ }^{1}$ Pantai Utara Laut Jawa (Pantura) identik dengan wilayah atau daerah di pesisir laut Jawa seperti Indramayu dan Cirebon.
} 
Selain perahu jegongan dan perahu sopean yang dikategorikan perahu dengan ukuran sedang, terdapat pula perahu berukuran sedang, terdapat pula perahu berukuran besar jenis kolek dan tembon, yakni perahu-perahu yang berukuran tembon lebar antara 3-6 meter serta panjang antara15-25 meter dengan awak kapal antara10-20 orang dan motor penggeraknya bertenaga 50 PK. Perahu-perahu berukuran besar ini biasanya milik nelayan pendatang yang berlabuh di pantai Eretan Wetan, karena alasan pencarian ikan di wilayah tersebut atau sedang mencari ikan.

Selain nelayan masyarakat Desa Eretan Wetan juga banyak sekali yang mencari nafkah sebagai pedagang, baik yang mempunyai kios atau warung, toko, ataupun pedagang keliling. Sedangkan profesi yang cukup dihormati oleh masyarakat Desa Eretan Wetan adalah Guru, Bidan, paraji, dan pamong praja. Karena orang Eretan Wetanmempunyai keyakinan bahwa seorang guru harus di gugu dan di tiru, karena dialah yang memberi kepintaran dalam bidang ilmu pengetahuan kepada mereka semua.Sedangkan dalam bidang pendidikan di Eretan Wetan terdapat TK 2 unit dengan jumlah guru 8 orang, jumlah mudid 80 orang di hitung rat-rata tiap tahun. Sedangkan Sekolah Dasar terdapat 1 unit dengan Jumlah murid 968 orang, dan 28 orang, dengan jumlah kelulusan 2054 orang. SLTP dan SMA hanya terdapat di tingkat Kecamatan dan Kabupaten. Jumlah kelulusan untuk SLTP 1258 orang sedangkan SMA 778 orang. Lulusan S1-S3 hanya 96 orang. Untuk jumlah lembaga pendidikan keagamaan terdapat 3 unit, dengan jumlah pesarta didik 100 orang dan pengajar 6 orang. Kebanyakan tradisi masyarakat Eretan Wetan lebih senang anaknya masuk pesantren atau Mondok dari pada ke sekolah umum. Hal ini yang mendorong dari mereka banyak yang belajar di pesantren Cirebon dan Jawa Timur. ${ }^{2}$ Dengan demikian, dapat dipahami ketika ada relokasi peternakan babi masyarakat Desa Eretan Wetan meresponnya dengan cepat disinilah kemudian muncul konflik antara Masarakat Desa Eretan Wetan yang memandang adanya peternakan babi secara tidak langsung melecehkan kenyamanan ibadah mereka yang notabenya beragama Islam dengan pemerintah Kabupaten Indramayu yang menerima adanya relokasi peternakan babi di Desa Eretan Wetan tersebut.

Jadi jelaslah perkembangan perekonomian Desa Eretan Wetan sangat terkait dengan tingkat pendidikan masyarakatnya sebagai referensi potensi sumber daya manusia untuk mewujudkan kehidupan yang sejahtra. Sebaliknya perkembangan desa akan menentukan apresiasi warga terhadap nilai-nilai sosiokultural tertentu dalam usaha menumbuhkan ekonomi yang lebih baik. Dialektika antara perkembangan desa, baik dalam memberikan makna sosial desa, distribusi sosial, segregasi etnis, pengelolaan berbagai

\footnotetext{
${ }^{2}$ Informasi ini diperoleh Daftar Isian Potensi Desa Dirjen Pemberdayaan Masyarakat dan Desa. Berdasarkan Surat Mendagri NO: 414.3/316/PMD. Tanggal 17 Pebruari 1995.
} 
sumber material dan berbagai perlembagaan atau pengorganisasian masyarakatanya ditentukan pula oleh tingkat pendidikan itu sendiri. ${ }^{3}$

Kemiskinan dan kesulitan-kesulitan hidup lainnya merupakan siklus peristiwa sosial ekonomi yang selalu berulang setiap tahun atau bahkan sepanjang tahun menimpa nelayan. Di samping persoalan lingkungan pesisir dan laut, kemiskinan nelayan merupakan isu besar yang terjadi karena faktorfaktor yang kompleks. Masalah kemiskinan nelayan merupakan masalah yang bersifat multi dimensi sehingga untuk menyelesaikannya diperlukan sebuah solusi menyeluruh. Untuk itu, terlebih dahulu harus diketahui akar masalah yang menjadi penyebab kemiskinan nelayan. Tulisan ini merupakan kajian studi pustaka dari beberapa sumber baik dari buku- buku, internet, maupun hasil penelitian penulis.

\section{Metode Penelitian}

Penelitian terkait strategi Mengatasi Kemiskinan di Nelayan Eretan Wetan, Indramayu menggunakan metode penelitian sejarah. Sedangkan untuk teori penulis gunakan teori kasusalitas yakni teori yang berbicara tentang sebab akibat terjadinya peristiwa sejarah, baik sebab langsung maupun tidak langsung. Dalam kausalitas, sejarawan menganalisis dua hal pokok, yaitu tentang problem dan solusi. Keduanya berbeda dalam akibat yang ditimbulkan, karena kasus lebih bersifat prosesual tanpa perubahan, sedangkan dalam perubahan terjadi perubahan kausalitas berupa perubahan struktural (struktural change) dan perubahan sistem (systemic chenge) (Gottsalk, 1995; Kuntowijoyo, 2008: 36-37).

\section{Stategi Mengatasi Kemiskinan Nelayan}

\section{Penyebab Kemiskinan}

Desa Eretan Wetan, Indrmayu termasuk daerah yang kompleks, namun hubungan antar warga terpelihara dengan baik. Warga pribumi Desa Eretan Wetan tidak merasa sebagai penduduk asli yang ingin menguasai karena kedudukannya sebagai tuan rumah, begitu pula sebagian penduduk yang lain sebagai warga pendatang juga bersikap demikian. Hubungan mereka terjalin sangat baik sesuai dengan kehidupan tradisional pedesaan. Pergaulan seharihari antara penduduk pribumi dan pendatang sangat terbuka sekali, demikian terbukanya perkawinan antar kerabat, juga perkawinan antara pribumi dan pendatangpun sering terjadi. Mereka saling menghormati dan bekerja sama dalam berbagai hal. Dalam peristiwa kematian, kecelakaan, orang sakit, atau hajatan, bantuan baik berupa tenaga maupun materi diberikan tanpa diminta.

\footnotetext{
${ }^{3}$ Zainudi Waliki , Agama Priyayi; Makna Agama di Tangan Elite Penguasa, (Yogyakarta: Pustaka Marawa, 2004), hlm.108-109.
} 
Di bidang peningkatan kesajahtraan masyarakat, pembangunan saluran air, perbaikan masjid dan madrasah dikerjakan secara bersama-sama pula.

Desa Eretan Wetan, Indramayu memiliki masyarakat yang bermata pencaharian sebagai nelayan maka wajar dalam kehidupan sehari-haripun sering melakuan ritual tadisional seperti nadran (pesta laut), yang dilakukan tiap satu tahun sekali. Sedangkan dalam berkomunikasi dengan penduduk setempat mereka menggunakan bahasa Jawa, adapun pendatang yang yang notabene berasal dari etnis Sunda, seperti dari Subang dan daerah Sunda yang lain dalam berkomunikasi sehari-hari menggunakan bahasa Sunda. Sedangkan di tempat-tempat forum resmi seperti di sekolah, kantor, dan tempat-tempat resmi lainnya menggunakan bahasa nasional.

Analisis menurut data pada Badan Pusat Statistik tahun 2010, terkait jumlah penduduk miskin di Indonesia mencapai 31.023.400 jiwa $(13,33 \%)$ dari jumlah penduduk sebanyak 237.641.326 jiwa. Dari jumlah penduduk yang miskin tersebut, sebanyak 19.925.600. jiwa (16,56 \%) tinggal di pedesaan. Penduduk yang tinggal di pedesaan di antaranya yang bermukim di daerah pesisir atau pantai yang umumnya bermatapencaharian sebagai nelayan. Kondisi masyarakat nelayan atau masyarakat pesisir di berbagai kawasan secara umum ditandai adanya beberapa ciri, seperti kemiskinan, keterbelakangan sosial-budaya, rendahnya kualitas sumberdaya manusia. Hal ini dikarenakan sebagian besar penduduk tingkat pendidikannya relatif rendah, hanya lulus Sekolah Dasar atau belum tamat Sekolah Dasar. Kemiskinan bisa terjadi karena dua hal yaitu kemiskinan alamiah dan buatan. Kemiskinan alamiah terjadi akibat sumber daya alam yang terbatas, penggunaan teknologi yang rendah dan bencana alam. Kemiskinan buatan terjadi karena lembaga-lembaga yang ada di masyarakat, membuat masyarakat tidak mampu menguasai sumber-sumber ekonomi dan fasilitas yang tersedia hingga membuat mereka tetap miskin. Sisi lain pemerintah lebih menitik beratkan pada pertumbuhan pembangunan daripada pemerataan pembangunan (Kusnadi, 2008:V).

Ada tiga dimensi yang menyebabkan nelayan miskin. Pertama, Dimensi Ekonomi, kurangnya sumberdaya yang dapat digunakan untuk meningkatkan kesejahtraan orang, baik secara finansial maupaun segala jenis kekayaan yang dapat meningkatakan kesejahtraan masyarakat. Kedua, Dimensi Sosial Budaya, kekuarangan jaringan sosial dan struktur yang mendukung untuk mendapatkan kesempatan agar produktifitas seorang meningkat. Ketiga, Dimensi Sosial Politik, rendahnya derajat akses terhadap kekuatan yang mencakup tatanan sistem sosial politik selain tiga dimensi tersebut, penyebab kemiskinan nelayan Eretan Wetan juga sebagai berikut.

a. Kondisi alam: Kompleksnya permasalahan kemiskinan masyarakat nelayan terjadi disebabkan masyarakat nelayan hidup dalam suasana alam yang keras dan selalu diliputi ketidak-pastian. Musim paceklik yang selalu 
datang tiap tahun dan lamanya pun tidak dapat dipastikan sehingga akan membuat nelayan terus berada dalam lingkaran kemiskinan.

b. Tingkat pendidikan nelayan: Nelayan yang miskin umumnya belum banyak tersentuh teknologi modern, kualitas sumber daya manusia rendah dan tingkat produktifitas juga sangat rendah. Tingkat pendidikan nelayan berbanding lurus dengan teknologi yang dapat dihasilkan oleh para nelayan, dalam hal ini teknologi di bidang penangkapan dan pengawetan ikan. Oleh karena itu, diperlukan teknologi pengawetan ikan teknologi penangkapan yang baik. Selama ini, nelayan hanya menggunakan cara yang tradisional untuk mengawetkan ikan. salah satunya disebabkan karenarendahnya tingkat pendidikan dan penguasaan nelayan terhadap teknologi.

c. Pola kehidupan nelayan: Stereotipe yang dipandang "boros sehingga oleh berbagai pihak sering dianggap penyebab kemiskinan nelayan. Padahal kultur nelayan jika dicermati justru memiliki etos kerja yang handal. Mereka pergi subuh pulang siang, pada waktu senggang memperbaiki jaring. Memang ada sebagian nelayan yang mempunyai kebiasaan dan budaya boros, sehingga hal tersebut menyebabkan posisi tawar masyarakat miskin semakin lemah.

d. Pemasaran hasil tangkapan: Tidak semua daerah pesisir memiliki Tempat Pelelangan Ikan (TPI). Hal tersebut membuat para nelayan terpaksa menjual hasil tangkapan mereka kepada tengkulak dengan harga di bawah harga pasaran.

e. Program pemerintah yang tidak memihak nelayan salah satunya dengan menaikan harga BBM, selama ini ketergantungan nelayan terhdap solar sangat tinggi. Selain itu proses pemangkasan kearifan lokal pada masa Orde Baru sangat tinggi, hingga mengakibatkan Bahari kita yang sangat kaya raya lebih dikuasai segelintir orang dan pihak asing.

\section{Potret Kondisi Sosial, Ekonomi dan Budaya Nelayan Eretan Wetan}

Para nelayan yang ada di Desa Eretan Wetan merupakan nelayan kecil yang menggunakan peralatan relatif sederhana dengan radius pencarian ikannya hanya sekitar pantai atau masih dalam zona Ekonomi Eksklusif (ZEE). Perahu yang digunakan di sekitar pantai merupakan perahu kecil yang di sebut Jukung dengan tenaga penggerak berupa dayung, digunakan pula beberapa peralatan untuk menangkap ikan di antaranya kain dan jaring ikan. Kapal lain yang lebih besar adalah jegongan dan sopean, yang hampir di miliki oleh para juragan. Semua perahu terbuat dari kayu yang dilengkapi dengan motor temple yang berkekuatan rata-rata $10 \mathrm{PK}$. Perahu jenis jegongan memiliki lebar antara 1,75-2 meter dengan panjang 6-10 meter berawak antara 2-4 orang, biasanya membawa jaring rampus, yaitu jaring yang lebar untuk menangkap berbagai jenis ikan seperti pari, kakap, tongkol. Sedangkan perahu 
sopean memiliki lebar anatara 2-2,5 meter dengan panjang kurang lebih12 meter, berawak 3-4 orang. Jaring yang dibawa oleh perahu sopean yaitu jaring kantong yaitu jarring yang dipergunakan untuk menjaring udang.

Selain perahu jegongan dan perahu sopean yang dikategorikan perahu dengan ukuran sedang, terdapat pula perahu berukuran sedang, terdapat pula perahu berukuran besar jenis kolek dan tembon, yakni perahu-perahu yang berukuran tembon lebar antara 3-6 meter serta panjang antara15-25 meter dengan awak kapal antara10-20 orang dan motor penggeraknya bertenaga 50 PK. Perahu-perahu berukuran besar ini biasanya milik nelayan pendatang yang berlabuh di pantai Eretan Sedangkan dalam bidang pendidikan di Desa Eretan Wetan terdapat TK 2 unit dengan jumlah guru 8 orang, jumlah mudid 80 orang di hitung rat-rata tiap tahun. Sedangkan Sekolah Dasar terdapat 1 unit dengan Jumlah murid 968 orang, dan 28 orang, dengan jumlah kelulusan 2054 orang. SLTP dan SMA hanya terdapat di tingkat Kecamatan dan Kabupaten. Jumlah kelulusan untuk SLTP 1258 orang sedangkan SMA 778 orang. Lulusan S1-S3 hanya 96 orang. Untuk jumlah lembaga pendidikan keagamaan terdapat 3 unit, dengan jumlah pesarta didik 100 orang dan pengajar 6 orang. Kebanyakan tradisi masyarakat Eretan Wetan Kecamatan Kandanghaur lebih senang anaknya masuk pesantren atau Mondok dari pada ke sekolah umum. Hal ini yang mendorong dari mereka banyak yang belajar di pesantren Cirebon dan Jawa Timur Informasi ini diperoleh Daftar Isian Potensi Desa Dirjen Pemberdayaan Masyarakat dan Desa. (Mendagri NO: 414.3/316/PMD. Tanggal 17 Pebruari 2005).

Penduduk Desa Eretan Wetan dalam data Monografi yang penulis dapatkan dari aparatur desa setempat hampir sebagian besar penduduknya beragama Islam. Sebanyak 9664 orang memeluk agama Islam. Walaupun dalam pelaksanaan ibadahnya tidak berbanding lurus dengan kuantitas tersebut di atas, tempat-tempat ibadah rata-rata berdekatan dengan tempat tinggal mereka. Secara kesaluruhan tempat ibadah itu berupa masjid 2 buah dan mushola 13 buah. Adapun penduduk minoritas di luar agama Islam adalah penganut Agama Kristen, yaitu berjumlah 71 orang, tetapi sarana ibadah di tingkat Desa Eretan Wetan berupa gereja tidak ada. Mereka yang akan melakukan kebaktian seringkali pergi ke Kecamatan atau kabupaten. ${ }^{4}$

Selain sarana ibadah, pendidikan yang berdasarkan agama Islam cukup menonjol di Desa Eretan Wetan ini. Tercatat 2 buah pondok pesantren, dengan dengan jumlah santri 80 orang pertahunnya, dan guru agama atau ustadz 8 orang. Sedangkan perkumpulan tokoh agama Islam ditingkat Kecamatan Kandanghaur sendiri tergabung dalam 15 majelis talim.

\footnotetext{
${ }^{4}$ Sumber informasi diperoleh dari Departemen Agama Kabupaten Indramayu pada hari Kamis tanggal 10 Agustus 2006. Berdasarkan keterangan sampai tahun 1996.
} 
Pada masarakat Desa Eretan Wetan, lapisan sosial yang berdasarkan umur digolongkan kedalam tiga bagian yakni pertama; sesepuh atau kaum tua biasanya berusia 50 tahun ke atas, kedua; kaum muda biasanya mereka yang masih belum menikah, walaupun usianya sudah 40 tahun kalau belum berumah tangga belum digolongkan kedalam golongan sesepuh dan ketiga; golongan anak-anak, biasanya mereka yang masih belum aqil baligh dianggap kategori ini. Peranan orang tua atau sesepuh merupakan tempat orang bertanya, karena dianggap orang pintar yang memiliki kemampuan dan pengetahuan baik yang nyata maupun supranatural. Sesepuh di Masyarakat Eretan Wetan Kecamatan Kandanghaur bisanya di panggil dengan sebutan Kyai. $^{5}$

Sesepuh lain yang dianggap memiliki kemampuan supranatural adalah Mama Solihin. Di rumahnya terdapat benda-benda gaib yang di percaya memiliki kemampuan supranatural seperti bebatuan permata, keris, cincin dan lainnya. Menurut mama Solihin benda-benda gaib itu harus diberi makan doa dan wirid agar tidak marah dan memiliki kesaktian. Tidak setiap orang bisa dipercaya mampu memberikan makan dan wirid, orang tersebut harus mampu melakukan laku lampah seperti semedi, dan puasa. Karena itulah warga Eretan Wetan mempercayai mama Solihin sebagai orang pintar yang bisa menjembatani dengan yang gaib. Setiap malam Jum'at kliwon banyak warg a yang datang ke rumahnya untuk melakukan prosesi ritual benda-benda gaib dan wiridan.

Lapisan lain adalah mereka yang memiliki ilmu tinggi di bidang agama Islam. Pemuka agama Islam yang ada di Eretan Wetan Kecamatan Kandanghaur biasa di panggil ustad. Peranan ustad sangat penting di masyarakat yakni sebagai pemimpin dalam setiap upacara perkawinan,

\footnotetext{
${ }^{5}$ Pada tahun 1960, para peneliti Barat seperti Geertz memperkenalkan kedalam literature antropologi istilah kiai. Ia menggunakan istilah itu menunjukan bahwa kiai sebagai makelar budaya (Culture broker). Di Indonesia sendiri untuk menyebut tokoh agama ada kiai ada juga ulama. Kedua istilah ini perbedaannya sangat penting, tidak hanya untuk tujuan kita masyarakat awam, akan tetapi juga bagi kaum muslimin. Untuk tujuan kita sebagai masyarakat awam, perbedaan itu menghendaki peranmgkat hibungan, harapan dan pola sikap yang berbeda dan untuk kaum muslimin perbedaan itu membantu stuktur kepemimpinan Islam. Perbedaan kiai seperti di jelaskan Zamakhsari Dhofier, yang mengatakan bahwa ahliahli pengetahuan Islam di kalangan umat Islam di sebut ulama. Di Jawa Barat mereka di sewbut Ajengan. Di Jawa Tengah dan Jawa Timur ulama yang memimpin pesantren di sebut kiai, dalam bahasa Madura di sebut Bendara di singkat $r a$.' Menurutr asal-usulnya perkataan kiai dalam bahasa Jawa dipakai untuk tiga hal jenis yang berbeda: Pertama; sebagai gelar kehormatan untuk barang-barang atau benda-benda yang dianggap keramat. Misalnya."Kiai Garuda Paksi Nagaliman.” Dipakai untuk sebutan kereta emas yang ada dikeraton Yogyakarta dan Cirebon. Kedua gelar kehormatan bagi orang tua pada umumnya. Dan ketiga; gelar yang diberikan masyarakat kepada seorang ahli Agama Islam yang menjadi pemimpin pesantren dan mengajar kitab-kitab Islam klasisk kepada para santrinya. Lebih lanjut lihat Zamaksari Dhofier, Tradisi Pesantren, (Jakarta: LP3ES 1982), hlm. 55.
} 
selamatan, kematian dan upacara daur hidup lainnya. Dalam bidang pendidikan agama Islam, peranan ustad cukup tinggi yakni mengajarkan nilainilai moral kepada anak muda. Pendidikan agama biasanya diberikan pada saat sesudah melakukan shalat di masjid atau mushola, bahkan sore hari ustad ini memberikan pelajaran agama pada anak-anak kecil. Pendidikan agama memang sangat penting bagi masyarakat Eretan Wetan Kecamatan Kandanghaur yang beragama Islam. Ustad Ali merupakan salah satu ustad yang cukup dihormati oleh masyarakat Eretan Wetan walaupun usianya masih muda tetapi dedikasinya untuk memajukan akhlak dan moral di desanya perlu diacungi jempol, oleh karena itu ustad Ali sering menjadi tempat bertanya oleh para generasi muda.

Satu lagi tokoh masyarakat yang cukup disegani yakni mereka yang di juluki Haji yaitu mereka yang menunaikan rukun Islam yang kelima di Makkah Al Mukaromah, seorang Haji ini biasanya memiliki materi atau kakayaan yang berlimpah. Salah satu tokoh terpandang di Eretan Wetan adalah Haji Usman. Dia adalah tuan tanah yang memiliki lahan yang luas, rumah besar, dan juga mempunyai perahu-perahu yang digunakan para nelayan untuk mencari ikan. Beliaulah orang dermawan yang berani mengeluarkan uangnya untuk membangun tempat-tempat ibadah baik masjid maupun mushola di Desa Eretan Wetan. Bahkan tak segan-segan memberikan dana untuk orang-orang yang membutuhkan pertolongan misalnya biaya sekolah atau berobat, memperbaiki jalan, biaya upacara tradisional seperti Ngunjung Buyut (Sedekah Karuhun), Nadran (Pesta Pantai), Mapag Sri (Upacara Penyambutan Datangnya Panen Padi) yang biasa dilakukan setaun sekali. Hal ini adalah sesuatu yang logis karena rata-rata orang yang menunaikan ibadah haji adalah orang kaya, menurut istilah Indramayu yang di Ungkapkan Haryanto Harhara; pati-pati munggah haji pasti bae wong sugih ( orang yang naik haji pasti orang yang kaya dan punya uang berkecukupan). ${ }^{6}$

Memang benar apabila kita analisis dari penjelasan di atas ritual keagamaan masyarakat Eretan Wetan Kecamatan Kandanghaur lebih dominan dilakukan oleh mereka yang beragama Islam, karena mereka yang beragama Kristen hanya tiap hari Minggu melakukan kebaktian di Gereja itupun harus berangkat ke Kota (Kecamatan atau Kabupaten). Karena di Desa Eretan Wetan tidak terdapat tempat ibadah untuk mereka yang non muslim.

Jadi jelaslah perkembangan perekonomian Desa Eretan Wetan sangat terkait dengan tingkat pendidikan masyarakatnya sebagai referensi potensi sumber daya manusia untuk mewujudkan kehidupan yang sejahtra. Sebaliknya perkembangan desa akan menentukan apresiasi warga terhadap nilai-nilai sosiokultural tertentu dalam usaha menumbuhkan ekonomi yang

\footnotetext{
${ }^{6}$ Keterangan Haryanto Harhara, Hari Rabu tanggal 9 Agustus 2017, pukul 19.21 wib.
} 
lebih baik. Dialektika antara perkembangan desa, baik dalam memberikan makna sosial desa, distribusi sosial, segregasi etnis, pengelolaan berbagai sumber material dan berbagai perlembagaan atau pengorganisasian masyarakatanya ditentukan pula oleh tingkat pendidikan itu sendirietan, karena alasan pencarian ikan di wilayah tersebut atau sedang mencari ikan.

Sisi lain masyarakat Indramayu memiliki keunikan karena memiliki kebudayaan berbeda dengan sebagian besar wilayah di Jawa Barat yang berbudaya Sunda. Indramayu seperti sebuah tempat yang isinya menjadi tarik menarik antara budaya Sunda dan budaya Jawa. Namun budaya Jawa yang ada Indramayu kadang tidak diklasifikasikan sebagai bagian dari budaya Jawa karena terdapat berbagai perbedaan. Budaya Indramayu atau sering disebut budaya Dermayu dapat dikatakan serumpun dengan budaya Cirebon. Namun budaya Dermayu dan Cirebon pun memiliki perbedaan sehingga terkadang keduanya tidak dimasukan dalam satu klasifikasi, tapi berdiri masing-masing dengan segala persamaan dan perbedaannya (Kasim, 2013: 10).

Pada umumnya bahasa Jawa yang digunakan di Cirebon dan di Indramayu masih bisa disebut sebagai bahasa Jawa, bukan bahasa Dermayu atau bahasa Cirebon. Hanya terdapat perbedaan dialek sehingga bisa disebut bahasa Jawa dialek Cirebon dan bahasa Jawa dialek Indramayu. Akan tetapi, bagi masyarakat Cirebon maupun Indramayu, sebagai bentuk kebanggaan terhadap bahasa yang digunakan, mereka tetap menganggap bahwa bahasa mereka merupakan bahasa tersendiri. Sebagai bukti kebanggaan tersebut sering diadakan seminar bahasa Indramayu atau seminar bahasa Cirebon di masing-masing daerah

\section{Usaha Mengatasi Kemiskinan Nelayan Eretan Wetan}

Masalah kemiskinan adalah problem yang nyata harus dituntaskan. Menurut Menteri Kelautan dan Perikanan Susi, Pemberdayaan hasil tangkapan laut harus seimbang untuk mewujudkan kesejahtraan nelayan pada umumnya dan pemerataan kesejahtraan suluruh masyarakat Indonesia, hal ini menjadi tanggung jawab semua pihak. Untuk itu dalam mengentaskan kemiskinan nelayan perlu keterpaduan atara pemerintah, dan melibatkan peran serta seluruh masyarakat termasuk didalamnya nelayan itu sendiri. Usaha dalam mengentaskan kemiskinan dimulai dengan program penanganan dan penangglangan desa tertinggal, program pemberdayaan masyarakat pesisir dana oprasional nelayan, lembaga donor seperti Lembaga Swadaya Masyarakat (LSM) dari pihak swasta yang melibatkan masyarakat sebagai pendamping program pemerintah dan pancingan penggerak masyarakat nelayan tradisional dan yang utama adalah membuat Koprasi yang penanganannya oleh nelayan Eretan Wetan dengan panduan para profesional. Di Eretan kini sudah terbentuk Koprasi Unit Desa Musyaya Mina, yang telah mewujudkan pembangunan Masjid dan sekolah Musaya Mina semuanay hasil 
swadaya dari masyarakat. Hal ini suatu kebanggaan bagi masyarakt Indramayu. Bahkan tahun 2001 DKM masjid Musaya mina melakukan santunan yatim piatu di kecamatan Kandanghaur.

Peranan perempuan, atau istri nelayan juga sangat penting untuk menstabilkan ekonomi nelayan. Istri nelayan juga harus diberdayakan untuk menopang ekonomi keluarga. Ketika suami mereka mencari ikan dilaut para istri juga berusaha mendapat pos pemasukan dari cara pengolahan ikan (membuat ikan asin, terasi dan sebaginnya), membuat ketramilan seperti jaring, tambang dan alat-alat menangkap ikan. Semuanya memang perlu pendamipingan di sinilah peran Lembaga Swadaya Masyarakat untuk membantu mengadakan pelatihan ketramiplan (TIM Pemberdayaan Masyarakat Pesisir, 2007:1).

Pembedayaan Masyarakat nelayat Eretan Wetan, Indramayu memiliki tujuan untuk mencapai kesejahtraan sosial budaya dan ekonomi. Hal ini menjadi fondasi awal pada basis Civil society. Maka untuk mencapai hal tersebut semua stuktur masyarakat dari mulai aparan desa, tokoh masyarat, pemerintah pusat dan daerah, LSM harus ikut peduli mewujudkannya.

Selanjutnya harus ada sinkronisasi pemberdayaan program pemerintah pusan kementrian dan pemerintahan daerah sampai tingkat desa tentang penanganan kemiskinan nelayan agar dampak positif untuk mengentaskan kemiskinan di Eretan Wetan, Indramayu cepat tercapai.

Dari seluruh rangkaian penanganan kemiskinan nelayan yang sangat penting adalah keterpaduan penanganan kemiskinan nelayan, dari mulai perencanaan kebijakan pemerintah, penangungjawab pelaksanaan program, kesiapan sumberdaya nelayan, pembedayaan hasil tangkapan laut, keterpaduan pemecahan masalah di nelayan, keterpaduan pemerataan sektor kelautan dan perikanan ditingkat lokal.

\section{Simpulan}

Nelayan dan kekayaan laut tidak bisa dipisahkan. Indonesia dengan kekayaan maritim harus dijaga dan diberdayakan pemanfaatannya. Salah kelola akan berdampak besar akan kelangsungan hidup penerus bangsa yang akan datang. Problem kemiskinan masyarat pesisir pada umumnya disebabkan akrena tidak terpenuhinya kebutuhan dasar. Kebutuhan akan terpenuhinya sandang, papan, pangan, kesehaan dan fasilitas pendidikan, keagamaan. Sisi lain kurangnya akses informasi, upaya dalam proses berusaha, melakukan inovasi pemberdayaan tangkapan laut, tekonologi dan permodalan, kekuatan pemahaman keagamaan, dan gaya hidup membuat posisi daya tawar masyarakat miskin semakin lemah dan dilemahkan. Kebijakan pemerintah yang telat menyadari pentingnya posisi maritim kenegaraan dan kurang peduli terhadap masyarakat pesisir harus segera disikapi dengan program yang terstruktur dan masif. 
Penanganan kemiskinan nelayan Eretan Wetan, Indramayu juga tidak sepenuhnya disikapi pemerintah, harus ada andil bersama seluruh lapisan masyarakat untuk melucuti kemiskinan nelayan. Terlebih lagi andil pihak swasta yang pro rakyat kecil, Lembaga Swadaya Masyarakat (LSM). Program pemerintah akan lebih konkrit jika mampu menjawab realitas yang terjadi, dengan memberikan pembedayaan pada nelayan dengan porsi sebagai subyek pada nelayan yang selama ini selalu diposisikan sebagai objek.

Kesinambungan program pemerintah, non pemerintah harus diawali dengan data yang akurat terkait kemaritiman dan nelayan sebagai dua aspek sumber daya alam dan sumber daya manusia. Karena studi kasus nelayan Eretan wetan, Indramayu tentunya bisa jadi tidak sama cara penangulangan kemiskinan di wilayah masyarakat pesisir yang lain. Sampai laporan penelitian ini dibuat. Koprasi Musyaya Mina Eretan Wetan masih tetap berdiri dan mampu memberdayakan Yayasan Pendidikan, dan pembangunan Masjid. 


\section{Daftar Pustaka}

Abdullah Ali, (2007) Tradisi Kliwonan Gunung Djati Model Wisata Religi Kabupaten Cirebon, Cirebon: Pemkab Cirebon bekerjasama Penerbit Cakrawala

Atja. (1986). Carita Purwaka Caruban Nagari. Bandung: Proyek Pengembangan Permuseuman Jawa Barat.

Fuad Hasan, (1989). Renungan Budaya, Penerbit: Balai Pustaka, Jakarta.

Kusnadi, dkk, (2006). Perempuan Pesisir. Yogyakart: LKiS.

--------, (2007). Jaminan Sosial Nelayan. Yogyakart: LKiS.

-------, (2008). Akar Kemiskinan Nelayan. Yogyakarta: LKiS.

Karyadi Mintaroem dan Mohammad Imam Farizi, 2008. "Pemberdayaan Nelayan dalam Upaya Mengurangi Kemiskinan di Kalangan Nelayan Indonesia," diakses tanggal 28-3 2012.

Nur Syam, (2011) Agama Pelacur Dramaturgi Transendental, Yogjakarta: LKIS. , (2011) Madzhab-Madzhab Antropologi, Jogjakarta: LKIS. , (2013)Tarekat Petani, Fenomena Tarekat Syattariyah Lokal, Yogyakarta: LkiS.

Sindu Galba, (2003). Budaya Tradisional pada Masyarakat Indramayu, Penerbit: Balai Kajian Sejarah dan Nilai Tradisional, Bandung.

Sukari, (2011). "Peranan Perempuan Dalam Rumah Tangga Nelayan Kasus di Desa Branta

Pesisir Kecamatan Tlanakan Kabupaten Pamekasan," Laporan Penelitian.Yogyakarta: BPSNT.

Supali Kasim, (2011). Menapak Jejak Sejarah Indramayu. Yogyakarta: Frame

Publishing. , (2013). Budaya Dermayu: Nilai Nilai Historis Estetis dan Transendental. Yogyakarta: Poestakadjati.

Tim Pemberdayaan Masyarakat Pesisir PSKP Jember, 2007. Strategi Hidup Masyarakat

Nelayan. Jember: LKiS.

Wahyu Iryana, (2016). Momi Kyoostutu. Jakarta: Kaki Langit Grasindo Group.

Widada, dkk, (2001). Kamus Basa Jawa (Bausastra Jawa). Yogyakarta: Kanisius.

Zaini Fajri, (2004). Kehidupan Sosial, Budaya, dan Ekonomi Masyarakat Nelayan (Studi pada 
Strategi Mengatasi Kemiskinan...... | Wahyu Iryana

$102 \mid \mathrm{H}$ is t o r i a M a d a $\mathrm{n}$ i a 